\title{
The application of low pressure storage to maintain the quality of zucchinis
}

Penta Pristijono, Michael C. Bowyer, Christopher J. Scarlett, Quan V. Vuong, Costas E. Stathopoulos and John B. Golding

This is an Accepted Manuscript of an article published by

Taylor \& Francis in New Zealand Journal of Crop and Horticultural Science on 11th October 2017, available online: http://wwww.tandfonline.com/10.1080/01140671.2017.1383277 
1 The application of low pressure storage to maintain the quality of zucchinis

2

3 Penta Pristijono $^{1 *}$, Michael C. Bowyer ${ }^{1}$, Christopher J. Scarlett $^{1}$, Quan V. Vuong ${ }^{1}$,

4 Costas E. Stathopoulos ${ }^{2}$, and John B. Golding ${ }^{1,3}$

$5{ }^{1}$ School of Environmental and Life Sciences, University of Newcastle, Ourimbah, NSW

62258 , Australia

$7 \quad{ }^{2}$ School of Science, Engineering and Technology, University of Abertay, Dundee DD1

$8 \quad$ HG, UK

$9 \quad{ }^{3}$ NSW Department of Primary Industries, Gosford, NSW 2250, Australia

10

11 *Corresponding author: Dr Penta Pristijono; email: penta.pristijono@ newcastle.edu.au;

12 School of Environmental and Life Sciences, University of Newcastle, PO Box 127,

13 Ourimbah - NSW 2258, Australia.

14

15 


\section{Abstract}

17 Zucchini (Cucurbita pepo var. cylindrica) were stored at low pressure (4 kPa) at

$1810^{\circ} \mathrm{C}$ at $100 \%$ relative humidity $(\mathrm{RH})$ for 11 days. Fruit quality was examined upon

19 removal and after being transferred to normal atmosphere $(101 \mathrm{kPa})$ at $20^{\circ} \mathrm{C}$ for three

20 days. Zucchinis stored at low pressure exhibited a 50\% reduction in stem-end browning

21 compared with fruit stored at atmospheric pressure $(101 \mathrm{kPa})$ at $10^{\circ} \mathrm{C}$. The benefit of

22 low pressure treatment was maintained after the additional three days storage at normal

23 atmospheric pressure at $20^{\circ} \mathrm{C}$. Indeed, low pressure treated fruit transferred to regular

24 atmosphere $20^{\circ} \mathrm{C}$ for three days possessed a significantly lower incidence of postharvest

25 rot compared to fruit stored at regular atmospheric pressure at $10^{\circ} \mathrm{C}$. Zucchinis stored at

26 low pressure showed higher levels of acceptability (28\% and $36 \%$ respectively)

27 compared to fruit stored at regular atmospheres at $10^{\circ} \mathrm{C}$ for both assessment times.

28 Keywords: postharvest; storage; refrigeration; vegetables; stem-browning 
Zucchini, also known as courgette (Cucurbita pepo var. cylindrica) are an important vegetable crop around the world (Esquinas-Alcazar and Gulick, 1983).

Zucchini is a non-climacteric fruit that is harvested at an immature stage, when the fruit reaches an average length of about $20 \mathrm{~cm}$ and the rind is still tender and edible (de Jesús

34 Avena-Bustillos et al., 1994; Megías et al., 2015). The thin skin of the fruit offers little barrier to water loss, leading to desiccation and rapidly softening if not refrigerated (Occhino et al., 2011).

However to store many chilling sensitive fruits and vegetables at low but nonfreezing temperatures induces fruit damage known as chilling injury (CI) (Sevillano et al., 2009). Zucchini fruit is particularly susceptible to this physiological disorder which is characterised by water loss, flesh rot, flesh softening and pitting of the fruit skin (Martínez-Téllezet al., 2002; Serrano et al., 1998). Carvajal et al. (2015) reported that zucchini fruits stored at $4^{\circ} \mathrm{C}$ for 3 days showed skin damaged due to CI. A minimum temperature of $7^{\circ} \mathrm{C}$ for commercial storage of zucchini is recommended to prevent significant economic loss (McCollum, 1990). postharvest quality in fruits and vegetables (Burg 2004). Low pressure storage has been known for many years and is a re-emerging technique that is homogeneous in application (Vigneault et al., 2012) which can rapidly remove the heat and reduce the concentration of oxygen and other harmful gases from the immediate storage environment (Wang et al., 2001). Many modern low pressure treatment systems are now capable of maintaining high humidity levels within the treatment chamber, which reduces water loss and wilting in the produce and reduces respiration and endogenous

53 ethylene production to delay fruit ripening (Burg, 2004). Low pressure storage can also 
54 reliably and consistently adjust the internal temperature and composition of the storage atmosphere (Li et al., 2006).

There is limited scientific literature regarding the effect of low pressure storage on the quality of zucchinis. However, there are reports on the effect of low pressure storage on the quality of Cucurbitacea of which zucchini is a family member. For example, low pressure treatment improved the quality of "Acorn" squash (McKeown \& Lougheed, 1981) and cucumbers (Burg, 2004). However Burg (2004) observed that there was no quality improvement for "Yellow crookneck" squash stored at low pressure. The objective of this study was to examine the effectiveness of low pressure storage $(4 \mathrm{kPa})$ at $10^{\circ} \mathrm{C}$ for 11 days with an additional short shelf-life at regular pressure $(101 \mathrm{kPa})$ at $20^{\circ} \mathrm{C}$ to maintain zucchini fruit quality postharvest.

\section{Materials and methods}

\section{Fruits}

Fresh, locally grown zucchini fruit (Cucurbita pepo var. cylindrica) free from damage and uniform in shape and size were obtained from a local commercial grower. Fruits between 20 and $22 \mathrm{~cm}$ in length and non-blemished were randomly selected, weighed and sorted into treatment units of 12 fruits.

\section{Low pressure storage system}

A laboratory scale low pressure system (VivaFresh ${ }^{\mathrm{TM}}$ ) with six identical low pressure aluminium chambers $\left(0.61 \mathrm{~L} \times 0.43 \mathrm{~W} \times 0.58 \mathrm{H} \mathrm{m}^{3}\right)$ was used in this study. Low pressure was achieved with a two-stage rotary vacuum pump (Model 2005I, Alcatel Adixen, USA) regulated by a compact proportional solenoid valve controlled by 
a proportional/integral/derivative (PID) computer control system equipped with an air flow controller to adjust the air exchange rate to prevent build-up of metabolic gases such as ethylene. A humidifier was used to ensure that inflowing air was correctly humidified before entering the low pressure chamber. Relative humidity was measured with a wet-bulb and dry-bulb temperatures using calibrated YSI 55000 Series GEM thermistors. Sensors inside the low pressure chambers were used to record the temperature, humidity and pressure during treatment. All data from temperature and pressure sensors in the low pressure system were recorded. The six different chambers were located inside two different cool rooms held at $10^{\circ} \mathrm{C}$.

88

\section{Experimental procedures of storage}

Individual experiments consisted of three different treatments; (a) control of fruit placed on a plastic tray at $101 \mathrm{kPa}$ at $20^{\circ} \mathrm{C}$ and $96 \% \mathrm{RH}$, (b) control of fruit placed on a plastic tray at $101 \mathrm{kPa}$ at $10^{\circ} \mathrm{C}$ and $94 \% \mathrm{RH}$ and (c) placed in an unsealed plastic container $(45 \mathrm{~cm} \times 20 \mathrm{~cm} \times 15 \mathrm{~cm})$ stored in the low pressure chamber at $4 \mathrm{kPa}, 10^{\circ} \mathrm{C}$ and $100 \%$ RH. Controls (a) and (b) (b) were covered with a loose low density polyethylene (LDPE) plastic bag $(66 \mathrm{~cm} \times 58 \mathrm{~cm})$ to maintain $\mathrm{RH}$ around the produce during storage. Temperature and RH were monitored with calibrated TinyTag View 2

97 loggers. The experiment was replicated three times, where each replicate used a different independent low pressure chamber. The fruit was assessed immediately upon removal from storage after 11 days and again after additional three days storage in air at

100 regular pressure $(101 \mathrm{kPa})$ and temperature $\left(20^{\circ} \mathrm{C}\right)$.

101 
Fruit quality assessments parameters included; weight loss, stem-end browning,

104 colour, blossom-end rot, fruit firmness and overall acceptability. Weight loss was

105 calculated as a percentage based on the initial weight of zucchinis and weight after

106 storage.

107 The incidence of flesh (blossom end) rot was assessed visually and scored (1-5)

108 based on the percentage of total blossom end area affected by black or white rot; $1=$

109 severe rot $(>50 \%$ affected); $2=$ moderate rot (noticeable white or black rot of $30-50$

$110 \%) ; 3=$ slight rot (noticeable white or black rot of $10-30 \%) ; 4=$ slight rot (small white

111 or black spot); and $5=$ no rot. Flesh rot index was calculated according to Wang et al.,

112 (2015), with slight modifications as shown in Equation 1.

$$
\text { Rots index }(\%)=\left(\frac{\text { Rot score in each fruit } \times \text { number of fruit at the same rot score }}{\text { highest rot score } \times \text { number of fruit in the treatment }}\right) \times 100
$$

Stem-end discolouration was subjectively evaluated using a grading scale from 1 to 5 , where $1=$ severe browning ( $>60 \%$ browned); $2=$ moderate browning affecting $20-60 \%$ stem; $3=$ browning affecting $<20 \%$ stem; $4=$ slight browning (no longer

117 bright); and $5=$ no browning. Stem-end browning was calculated according to

118 Pristijono et al. (2017), with slight modifications, as shown in Equation 2.

$$
\text { Browning index }(\%)=\left(\frac{\text { Browning level in each fruit } \times \text { number of fruit at the same browning level }}{\text { Highest browning level } \times \text { total number of fruit in the treatment }}\right) \times 100
$$

122 Analyser, Fireman, UK) and estimated as the average maximum force (Newton)

123 required to push a $7 \mathrm{~mm}$ probe into the fruit flesh to a depth of $2 \mathrm{~mm}$. The average was

124 gained from 2 reading points taken from each side of the fruit at a distance of $5 \mathrm{~cm}$ from the blossom-end. 
127 (Minolta CR-400, Osaka) using the average of four point measurements taken at a distance of $5 \mathrm{~cm}$ from blossom end of the fruit.

130 of the level of stem-end browned, blossom-end flesh rotted and skin discolouring,

131 scoring from 1 to 4 , where, score $1=$ poor, not edible; 2 = not saleable but edible,

132 acceptable for cooking; $3=$ saleable, good marketable; and $4=$ excellent fresh with no 133 symptoms of flesh rots and discolouration. The overall acceptability index of fruit was 134 assessed according to Pristijono et al. (2017), with slight modifications as shown in 135 Equation 3.

Statistical analysis

Statistical analysis was performed using Statistical Analysis System - version was used to analyse the data. The mean values were evaluated by using least significant differences (LSD) test with $\mathrm{p}<0.05$ as statistical significance.

\section{Results and discussion}

Colour

147 Fruit colour was assessed upon removal from low pressure storage and again

148 after being stored at atmospheric pressure $(101 \mathrm{kPa})$ at $20^{\circ} \mathrm{C}$ for three days. There was

149 no significant difference in peel colour between fruit subject to low pressure storage

$150 \quad(4 \mathrm{kPa}) 10^{\circ} \mathrm{C}$ and fruit stored under regular atmospheric pressure $(101 \mathrm{kPa})$ either at 
$15110^{\circ} \mathrm{C}$ or $20^{\circ} \mathrm{C}$ storage temperature (data not shown). Hue angle did not change

152 significantly during storage at low pressure $(4 \mathrm{kPa})$ and regular pressure $(101 \mathrm{kPa})$ at

$15310^{\circ} \mathrm{C}$ for 11 days, remaining at a constant value of 122 . These observations are in

154 agreement with previous studies by Burg (2004) who showed that the peel of "Acorn"

155 squash remained green after fruits were stored at low pressure of $7.33-8 \mathrm{kPa}$ for 11

156 days at $7^{\circ} \mathrm{C}$.

Weight loss

Weight loss is a complex phenomenon propagating from mechanical, biological

160 and physical interactions. Weight loss can lead to wilting and shrivelling, both of which

161 reduce market value and consumer acceptability. Postharvest weight loss in vegetables

162 is usually due to the loss of water through transpiration (Znidarcic et al., 2010). After 11

163 days storage zucchinis stored at regular atmospheric pressure $(101 \mathrm{kPa})$ at $20^{\circ} \mathrm{C}$ resulted

164 in greater weight loss than fruit were stored at $10^{\circ} \mathrm{C}$ at pressures of 4 and $101 \mathrm{kPa}$

165 (Table 1). The results are in agreement with studies by De Castro et al. (2006) who

166 demonstrated that weight loss in tomato fruits stored at different temperatures was

167 proportional to the storage temperature.

168 The results presented in Table 1 show that water loss from the fruit stored in the

169 low pressure storage $\left(4 \mathrm{kPa}, 10^{\circ} \mathrm{C}\right)$ was higher than those stored at regular atmosphere

$170(101 \mathrm{kPa})$ at $10^{\circ} \mathrm{C}$ upon removal. This finding is in agreement with previous research by

171 Laurin et al. (2006) who reported that low pressure treatment of "Alpha-type"

172 cucumbers (70 $\mathrm{kPa}$ for 6 hours) increased weight loss. However it is very important to

173 consider all the variables assiociated with water loss and vapour presseure deficit, and

174 care should be taken when comparing studies. 
$176 \mathrm{kPa}$ ) at $20^{\circ} \mathrm{C}$, the fruit previously stored at low pressure did not show significant

177 differences in weight loss to zucchinis that were stored at regular atmosphere at $10^{\circ} \mathrm{C}$.

178 This observation is similar to report by Hashmi et al. (2013) who observed that the low

179 pressure treatment did not affect the weight loss of strawberries. However, these

180 observations contradict previous reports by Burg (2004) who reported that "Acorn"

181 squash stored under pressure of $7.33-8 \mathrm{kPa}$ at $7^{\circ} \mathrm{C}$ and $90-95 \% \mathrm{RH}$ for 11 days

182 resulted in loss of $4.2 \%$ its weight.

183

184 Firmness

185 Fruit firmness was assessed both immediately after the zucchinis were removed

186 from low pressure storage $\left(10^{\circ} \mathrm{C}, 11\right.$ days $)$ and again three days after transfer to storage

187 atmosphere $(101 \mathrm{kPa})$ and $20^{\circ} \mathrm{C}$. Fruit stored at $10^{\circ} \mathrm{C}$ under low pressure maintained

188 higher firmness values than fruit stored at regular atmosphere $(101 \mathrm{kPa})$ at $20^{\circ} \mathrm{C}(\mathrm{Table}$

189 1). The maintenance of fruit firmness was more obvious after the additional shelf-life

190 storage at $20^{\circ} \mathrm{C}$ for three days, with the low pressure treated fruit exhibiting

191 significantly greater firmness $(\mathrm{p}<0.05)$. However there was no difference in firmness

192 between fruits stored at low pressure $\left(4 \mathrm{kPa}, 10^{\circ} \mathrm{C}\right)$ and regular pressure $(101 \mathrm{kPa})$ at

$19310^{\circ} \mathrm{C}$. The findings are in agreement with previous work by Hashmi et al. (2016) who

194 found that low pressure treatment $(50 \mathrm{kPa})$ of strawberries had no beneficial effect of

195 fruit firmness. In this study, the differences in fruit firmness between low pressure (4

$\left.196 \mathrm{kPa}, 10^{\circ} \mathrm{C}\right)$ and regular pressure $\left(101 \mathrm{kPa}, 20^{\circ} \mathrm{C}\right)$ treatments maybe a result of difference

197 in water loss.

198

199 Blossom-end flesh rots 

end flesh rots, fungal decay including black rot, cottony leak and bacterial soft rots are 202 the principal factors contributing to spoilage (Burg, 2004). Low pressure treatment of

203 other horticultural produce such as cucumbers and bananas have been shown to

204 improved freshness, taste and flavour and reduced the incidence of deterioration

205 attributable to bacterial and fungal infection (Burg, 2004). In this study, zucchini fruit 206 exposed to low temperature reduced the incidence of blossom-end rot (Figure 1).

207 Further, the incidence of rot in the low pressure treated fruit stored for an additional 208 three days at atmospheric pressure $(101 \mathrm{kPa})$ and $20^{\circ} \mathrm{C}$ was significantly lower than

209 control fruit stored at $101 \mathrm{kPa}$ and $10^{\circ} \mathrm{C}$. The findings are in agreement reports by Wang 210 et al. (2015) who found that honey peaches stored at low pressure $(10-80 \mathrm{kPa})$ at $0^{\circ} \mathrm{C}$

211 for 30 days produced a significantly lower incidence of fruit rot. Hashmi et al. (2016) 212 also reported similar findings for strawberries treated at $50 \mathrm{kPa}$ at $5^{\circ} \mathrm{C}$ for 4 hours and 213 subsequently stored at $20^{\circ} \mathrm{C}$.

214 Differing levels of flesh rot between treatments stored at atmospheric and low 215 pressure at $10^{\circ} \mathrm{C}$ after removal to $20^{\circ} \mathrm{C}$ may be due to reduced oxygen availability 216 during low pressure treatment, where the oxygen $\left(\mathrm{O}_{2}\right)$ levels at $4 \mathrm{kPa}$ are approximately $2171 \% \mathrm{O}_{2}(\mathrm{v} / \mathrm{v})$. Burg (2004) has previously reported that low oxygen storage conditions $218\left(0.1-0.25 \% \mathrm{O}_{2}\right)$ have significantly inhibitory effects on pathogen and spore 219 germination.

Stem-end browning The fresh appearance of the stem-end of zucchini fruit is a major determinant in assessing fruit quality and acceptability. Low pressure storage at $10^{\circ} \mathrm{C}$ resulted in

224 significantly lower levels of stem-end browning compared to storage at $10^{\circ} \mathrm{C}$ under 
normal atmospheric pressure $(101 \mathrm{kPa})$, which were further significantly lower than storage at $20^{\circ} \mathrm{C}$ (Figure 2). These observations were similar immediately upon removal and after an additional three days storage at $20^{\circ} \mathrm{C}$, where the additional time resulted in an increase in stem-end browning, but the differences between the treatments remained the same. These findings are consitent with Gao et al. (2006) who observed that low

230 pressure storage conditions $\left(40-50 \mathrm{kPa}, 4^{\circ} \mathrm{C}\right.$ for 49 days) significantly reduced the incidence of browning in loquat fruit. However further mechanistic studies are required to determine whether a similar or different pathway for low pressure storage action occurs in reducing browning in stem-end of zucchinis.

Acceptability index

The overall acceptability of the zucchini fruit was visually assessed based on a combination of flesh rots and stem discolouration. Fruit stored at low pressure for 11 days had higher overall aceptability levels than fruit stored at atmospheric pressure for the same time period, either at $10^{\circ} \mathrm{C}$ or $20^{\circ} \mathrm{C}$ (Figure 3). Further, zucchinis previously

240 stored at low pressure for 11 days at $10^{\circ} \mathrm{C}$, followed by subsequent storage of the

241 atmospheric pressure (101 $\mathrm{kPa})$ for a further three days at $20^{\circ} \mathrm{C}$ showed the highest acceptability index (79\%) of all experimental treatments.These overall acceptability results were associated with reduced stem-end browning during storage and lower levels

244 of blossom-end flesh rot. These results show that zucchini fruit stored at low pressure (4 $245 \mathrm{kPa}$ ) combined with temperature storage of $10^{\circ} \mathrm{C}$ improved fruit quality by maintaining 246 overall freshness and acceptability.

\section{Conclusions}


In conclusion, the low pressure storage of $4 \mathrm{kPa}$ at $10^{\circ} \mathrm{C}$ for 11 days maintained

250 the quality of zucchinis during storage by reducing flesh rots, stem-end browning and

251 increased acceptability. This benefit was maintained with a subsequent shelf life

252 assessment for three days at $20^{\circ} \mathrm{C}$ in regular atmosphere $(101 \mathrm{kPa})$. The low pressure

253 storage also maintained firmness, colour and weight loss, similar to regular atmosphere

254 storage. Thus, the results of this experiment support the application of low pressure

255 storage for horticultural produce, but large scale experiments are required to be

256 conducted for the commercial validation and optimisation of low pressure storage.

258 Acknowledgements

The author would like to thank John Archer, David Cruikshank and Christine

260 Cruickshank at NSW DPI for assistance with the running and maintenance of the low

261 pressure chambers.

263 Funding

This work was supported supported by NSW Department of Primary Industries,

265 Horticulture Innovation Australia and AusVeg (Project VG13043). The project was also supported by the University of Newcastle and the Australian Research Council Training

267 Centre for Food and Beverage Supply Chain Optimisation (IC140100032).

269 References

270 Burg SP 2004. Postharvest physiology and hypobaric storage of fresh produce. E-Book.

271 CABI Publisher. 
272 Carvajal F, Palma F, Jamilena M, Garrido D 2015. Cell wall metabolism and chilling

273 injury during postharvest cold storage in zucchini fruit. Postharvest Biology and

274 Technology 108: 68-77. doi: http://dx.doi.org/10.1016/j.postharvbio.2015.05.013.

275 De Castro L, Cortez L, Vigneault C 2006. Effect of sorting, refrigeration and packaging

276 on tomato shelf life. Journal of Food, Agriculture and Environment 4: 70-74.

277 de Jesús Avena-Bustillos R, Krochta JM, Saltveit ME, de Jesús Rojas-Villegas R,

278 Sauceda-Pérez J 1994. Optimization of edible coating formulations on zucchini to

279 reduce water loss. Journal of Food Engineering 21: 197-214. doi:

280 http://dx.doi.org/10.1016/0260-8774(94)90186-4.

281 Esquinas-Alcazar JT, Gulick. PJ 1983. Genetic resources of cucurbitaceae.

282 International Board for Plant Genetic Resources, Rome, Italy.

283 Gao HY, Chen HJ, Chen WX, Yang YT, Song LL, Jiang YM, Zheng YH 2006. Effect

284 of hypobaric storage on physiological and quality attributes of loquat fruit at low

285 temperature. Acta Horticulturae 712: 269-274. doi: 10.17660/ActaHortic.2006.712.29.

286 Hashmi MS, East AR, Palmer JS, Heyes JA 2013. Hypobaric treatment stimulates

287 defence-related enzymes in strawberry. Postharvest Biology and Technology 85: 77-82.

288 doi: http://dx.doi.org/10.1016/j.postharvbio.2013.05.002.

289 Hashmi MS, East AR, Palmer JS, Heyes JA 2016. Hypobaric treatments of

290 strawberries: A step towards commercial application. Scientia Horticulturae 198: 407-

291 413. doi: http://dx.doi.org/10.1016/j.scienta.2015.12.017.

292 Laurin É, Nunes MCN, Émond JP, Brecht JK 2006. Residual effect of low-pressure

293 stress during simulated air transport on Beit Alpha-type cucumbers: Stomata behavior.

294 Postharvest Biology and Technology 41: 121-127. doi:

295 http://dx.doi.org/10.1016/j.postharvbio.2005.09.012. 
Li W, Zhang M, Yu H 2006. Study on hypobaric storage of green asparagus. Journal of

297 Food Engineering 73: 225-230. doi: http://dx.doi.org/10.1016/j.jfoodeng.2005.01.024.

298 Martínez-Téllez MA, Ramos-Clamont MG, Gardea AA, Vargas-Arispuro I. 2002.

299 Effect of infiltrated polyamines on polygalacturonase activity and chilling injury

300 responses in zucchini squash (Cucurbita pepo L.). Biochemical and Biophysical

301 Research Communications 295: 98-101. doi: https://doi.org/10.1016/S0006-

$302 \quad 291 X(02) 00631-9$.

303 McCollum T G 1990. Gene B influences susceptibility to chilling injury in cucurbita

304 pepo. Journal of the American Society for Horticultural Science 115: 618-622.

305 McKeown A, Lougheed E 1981. Low Pressure Storage of Some Vegetables. Acta

306 Horticulturae 116: 83-100. doi: 10.17660/ActaHortic.1981.116.12.

307 Megías Z, Barrera A, Manzano S, Martínez C, Garrido D, Valenzuela JL, Jamilena M

308 2015. Physical and chemical treatments enhancing postharvest fruit quality in zucchini.

309 Acta Horticulturae 1091: 141-146. doi : 10.17660/ActaHortic.2015.1091.17.

310 Occhino E, Hernando I, Llorca E, Neri L, Pittia P 2011. Effect of Vacuum

311 impregnation treatments to improve quality and texture of zucchini (Cucurbita Pepo, L).

312 Procedia Food Science 1: 829-835. doi: http://dx.doi.org/10.1016/j.profoo.2011.09.125.

313 Pristijono P, Scarlett CJ, Bowyer MC, Vuong QV, Stathopoulos CE, Jessup AJ,

314 Golding JB 2017. Use of low pressure storage to improve the quality of tomatoes. The

315 Journal of Horticultural Science and Biotechnology :1-8. doi:

316 http://dx.doi.org/10.1080/14620316.2017.1301222.

317 Serrano M, Pretel MT, Martínez-Madrid MC, Romojaro F, Riquelme F 1998. CO 2

318 Treatment of zucchini squash reduces chilling-induced physiological changes. Journal

319 of Agricultural and Food Chemistry 46: 2465-2468. doi: 10.1021/jf970864c. 
320 Sevillano L, Sanchez-Ballesta MT, Romojaro F, Flores FB 2009. Physiological,

321 hormonal and molecular mechanisms regulating chilling injury in horticultural species.

322 Postharvest technologies applied to reduce its impact. Journal of the Science of Food

323 and Agriculture 89: 555-573. doi: 10.1002/jsfa.3468.

324 Vigneault C, Leblanc DI, Goyette B, Jenni S 2012. Invited review: engineering aspects

325 of physical treatments to increase fruit and vegetable phytochemical content. Canadian

326 Journal of Plant Science 92: 373-397.

327 Wang J, You Y, Chen W, Xu Q, Wang J, Liu Y, Song L, Wu J 2015. Optimal

328 hypobaric treatment delays ripening of honey peach fruit via increasing endogenous

329 energy status and enhancing antioxidant defence systems during storage. Postharvest

330 Biology and Technology 101: 1-9. doi:

331 http://dx.doi.org/10.1016/j.postharvbio.2014.11.004.

332 Wang LP, Zhang P, Wang SJ 2001. Advances in research on theory and technology for

333 hypobaric storage of fruit and vegetable. Storage and Process 5: 3-6.

334 Znidarcic D, Ban D, Oplanic M, Karic L, Pozrl T 2010. Influence of postharvest

335 temperatures on physicochemical quality of tomatoes (Lycopersicon esculentum Mill.).

336 Journal of Food, Agriculture and Environment 8: 21-25.

337

338 
List of Tables

340 Table 1. Effect of low pressure storage on zucchinis' weight loss and firmness on

341 different assessment day at $20^{\circ} \mathrm{C}$.

342

343 List of Figures

344 Figure 1. The blossom-end rotting index of zucchinis exposed to different treatments.

345 The values are the mean of three replicates. The different letters indicate significant

346 differences between treatments for each storage time $(p<0.05)$.

347 Figure 2. The stem-end browning index of zucchinis exposed to different treatments.

348 The values are the mean of three replicates. The different letters indicate significant

349 differences between treatments for each storage time $(p<0.05)$.

350 Figure 3. The acceptability index of zucchinis exposed to different treatments. The

351 values are the mean of three replicates. The different letters indicate significant

352 differences between treatments for each storage time $(p<0.05)$.

353 
354 Table 1. Effect of low pressure storage on zucchinis' weight loss and firmness on 355 different assessment day at $20^{\circ} \mathrm{C}$.

356

\begin{tabular}{lcc}
\hline Treatments & Weight loss $(\%)$ & Firmness $(\mathrm{N})$ \\
\hline$\underline{\text { Time zero }}$ & - & 69.1 \\
Upon removal & & \\
$101 \mathrm{kPa} 20^{\circ} \mathrm{C}, 11$ days & 2.5 & 63.1 \\
$101 \mathrm{kPa} 10^{\circ} \mathrm{C}, 11$ days & 1.5 & 65.3 \\
$4 \mathrm{kPa} 10^{\circ} \mathrm{C}, 11$ days & 1.8 & 67.5 \\
$L S D(5 \%)$ & \pm 0.2 & \pm 3.3 \\
Additional storage 3 days at $101 \mathrm{kPa} 20^{\circ} \mathrm{C}$ & \\
$101 \mathrm{kPa} 20^{\circ} \mathrm{C}, 11$ days & 3.0 & 52.9 \\
$101 \mathrm{kPa} 10^{\circ} \mathrm{C}, 11$ days & 1.9 & 63.8 \\
$4 \mathrm{kPa} 10^{\circ} \mathrm{C}, 11$ days & 2.1 & 68.0 \\
$L S D(5 \%)$ & \pm 0.4 & \pm 7.5 \\
\hline Values are the mean of 3 replicates with 12 fruits in each replicate.
\end{tabular}


360

361

362

363

364

365

366

367

368

369

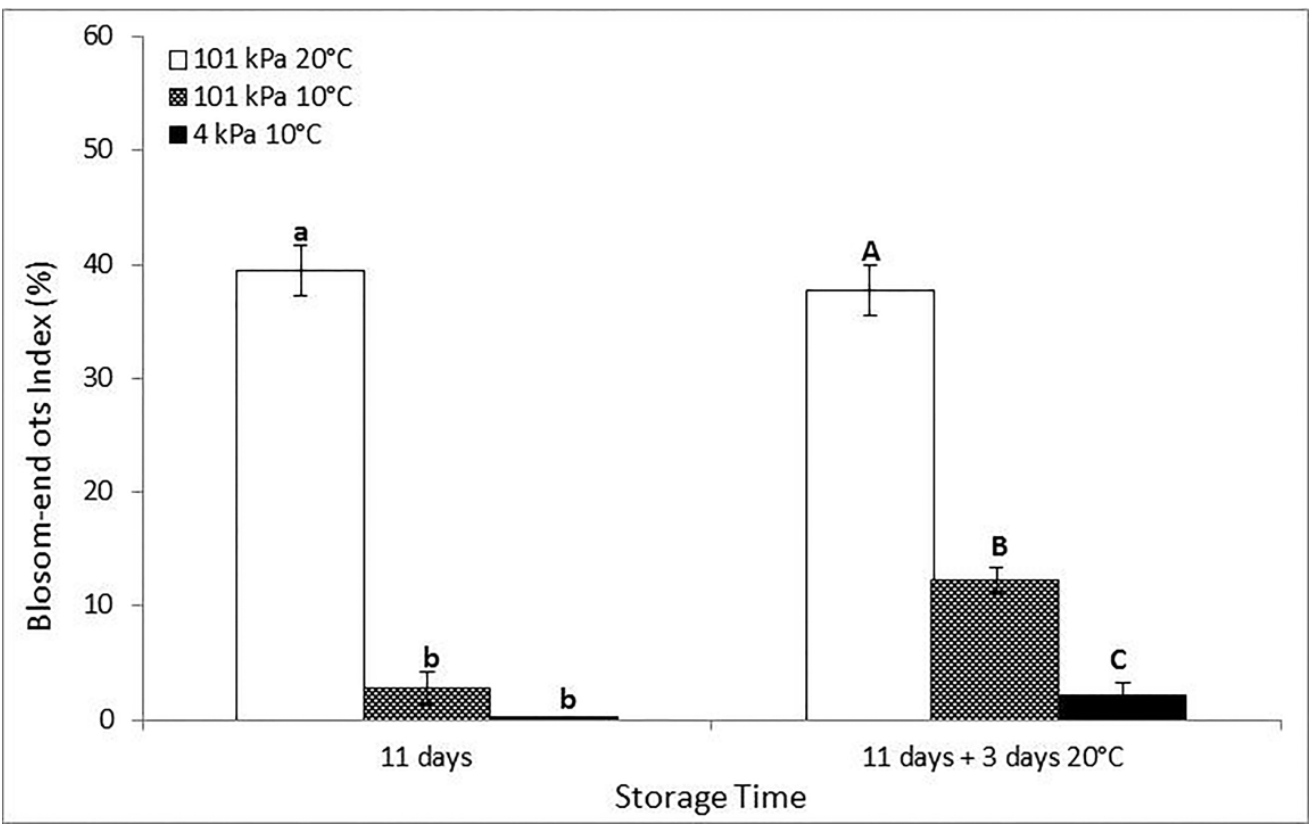

370

371 Figure 1. The blossom-end rotting index of zucchinis exposed to different treatments.

372 The values are the mean of three replicates. The different letters indicate significant

373 differences between treatments for each storage time $(p<0.05)$.

374 
376

377

378

379

380

381

382

383

384

385

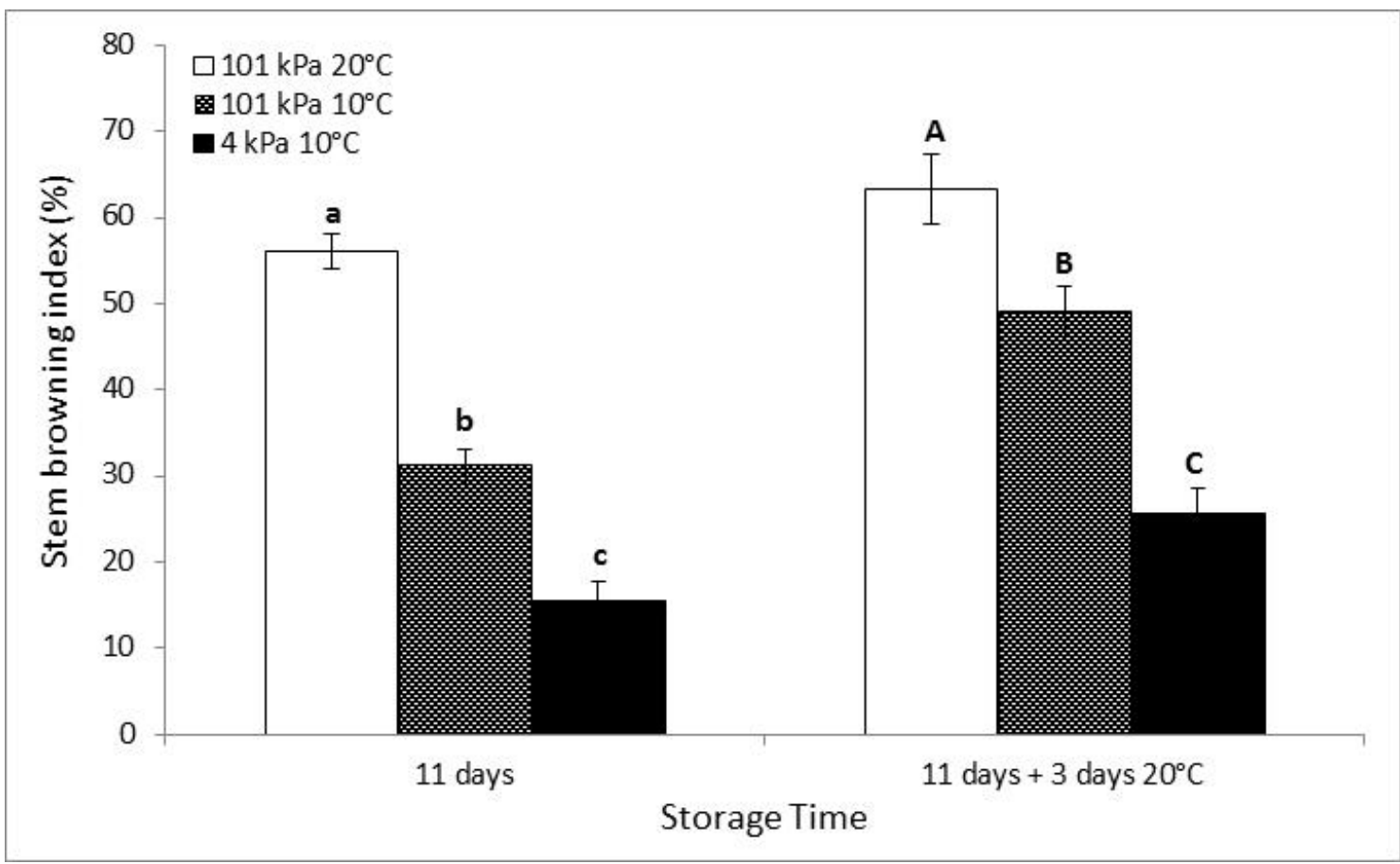

386

387 Figure 2. The stem-end browning index of zucchinis exposed to different treatments.

388 The values are the mean of three replicates. The different letters indicate significant

389 differences between treatments for each storage time $(p<0.05)$. 


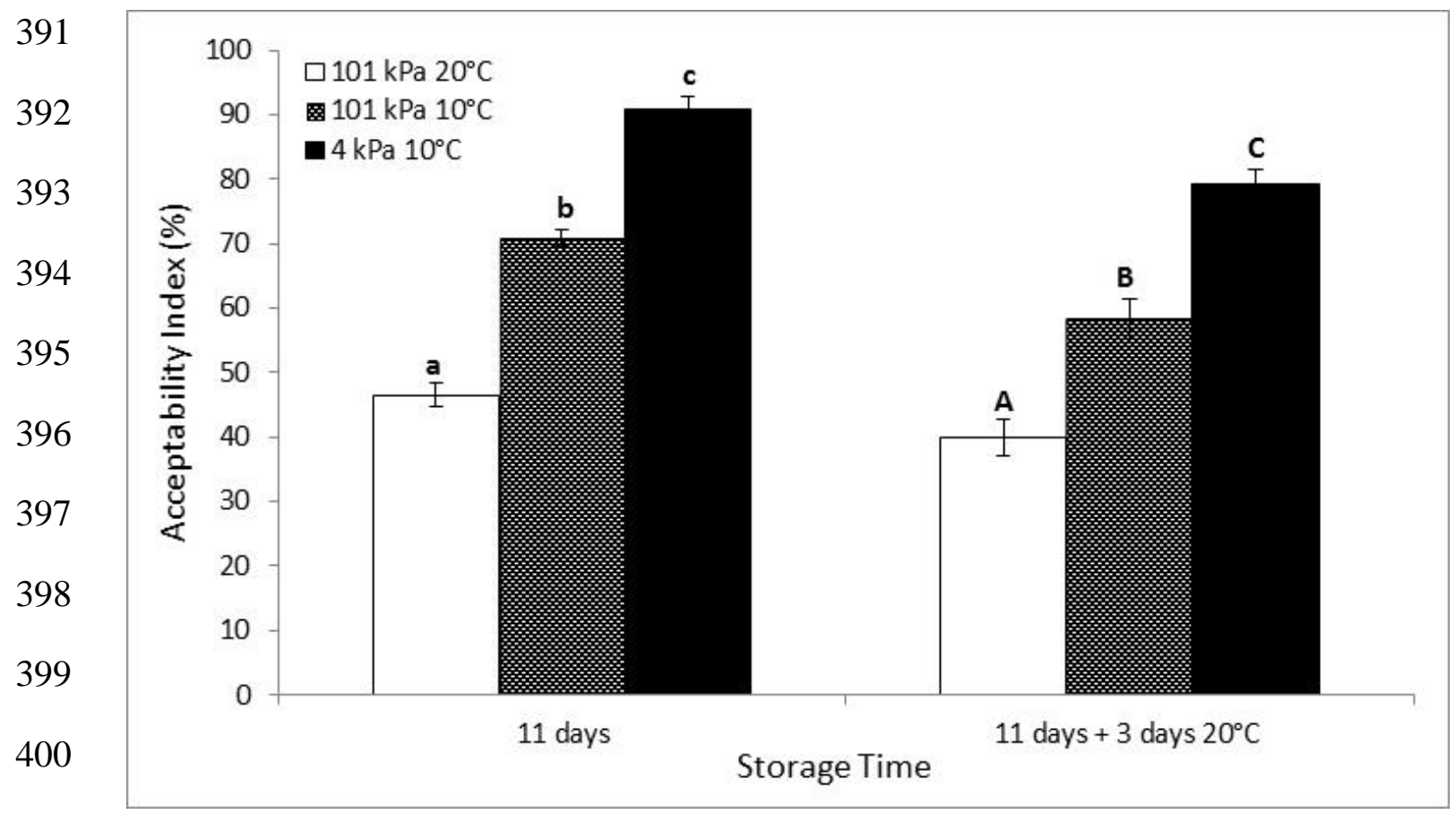

401

402 Figure 3. The acceptability index of zucchinis exposed to different treatments. The

403 values are the mean of three replicates. The different letters indicate significant

404 differences between treatments for each storage time $(p<0.05)$.

405

406

407

408 